\title{
The Imported Culture: Who Is the Dummy? Considering 'Agency' in the Circulation of Chinese Books in Europe during the Seventeenth-Eighteenth Centuries
}

\author{
Arianna Magnani \\ (Università Ca’ Foscari Venezia, Italia)
}

\begin{abstract}
Between the 17th and 18th century the European 'Republic of Letters' was characterised by a great interest in the 'Other' and the fascination with different, 'exotic' cultures. In this cultural environment, the Jesuit missionaries in China acted as a 'bridge' between the two continents exchanging information and books from each side. This paper discusses the use of the concept of 'agency' as applied to Chinese books, analysing how they were subjected to actions and, in turn, were capable of action, in this specific European context. The aim of this paper is to reflect how the agency of these texts conflicts and coincides with the agency of other actors connected with this trans-cultural process.
\end{abstract}

Summary 1 Introduction: Interpreting Agency and Text.-2 Actors in the Migration of Books. - 3 Agency in Translating: 'do ut des'. - 4 Agency on Value, Mutability of Things in Recontextualization. - 5 Agency in Constructing the Chinese Image: the Influence of Books. - 6 Conclusion.

Keywords Jesuits. Chinese Book Collections. Republic of Letters. Cross-cultural transfer. Imported Culture.

\section{Introduction: Interpreting Agency and Text}

The term of 'agency', used by scholars in every field of research, is full of ambiguity, stemming from several interrelated factors and definitions (Emirbayer, Mische 1998, 962).

Coming out of the late 1970s, ${ }^{1}$ the usage of this word grew from the reflection on how human actions can influence and be influenced by society, to a shift to a non-anthropocentric point of view and attribution of the

I would like to thank Prof. George L. Gorse for his help and suggestions, Prof. Attilio Andreini for his constant support, Sharon Sampaoli for the English correction and the anonymous reviewers for their helpful observations.

1 For a brief introduction to 'agency' and its history, see Ahearn 1999. 
same capacity to 'act' in inanimate objects.

When we analyse 'agency' in books, then, what do we want to express?

For Cooren $(2010,32)$, the concept of 'agency' applied to textual studies, implies the awareness that any kind of text has a relative autonomy, or better, has a 'life of its own', because it can continue to function in other contexts, even in the absence of its producers. This is particularly evident in the case of Imported culture, where books that are transferred from one place to another, severing ties with the habitat of production, are still 'living' on their own, acquiring new value and influence that differ from those for which they were created. Malafouris stated that:

while agency and intentionality may not be properties of things, they are not properties of humans either: they are the properties of material engagement, that is, of the grey zone where brain, body and culture conflate. (Knappett, Malafouris 2008, 22).

Agency then, does not reside completely in humans or things, but stays in between, and is connected in the most concrete way with the interrelationship of the two, inside the framework of society, culture, and history in which they are living.

Books are a product of society, that is interacting with it and its inhabitants, which allow us to say - using the metaphor of ventriloquism coined by Cooren - that books are puppets that

make us do things (we are then their dummies while they are our ventriloquists) as much as we make them do things (in which case, they are our dummies while we are their ventriloquists) $(2010,90)$.

This definition of 'agency' does not deny the property of actions to humans, but simultaneously recognizes to things their own way of acting through their use, as an infinite swirling Dervishes' dance, in which the performer, the dress and the tradition behind it all work together in order to be admired by the audience, that is also a part of the performance.

Starting from these interpretations of object agency, we will reflect on how texts can act and influence a society, and at the same time, be acted upon by it. As a case study, we will analyse the particular situation of books written in Chinese that arrived in Europe and were collected there between the seventeenth and eighteenth centuries. To simplify, we can say that the role of 'puppeteers' in this process of cultural migration was taken by the Jesuits, and books became their 'dummies'.

Nevertheless, as should be done in every show, we need to consider the full cast in order to ponder critically the result of this performance. 


\section{Actors in the Migration of Books}

In this process of cross-cultural consumption, we can identify at least six worthy agents: 1 ) the Chinese cultural consumers and producers; 2) the books; 3 ) the Chinese regulators of the cultural exportation; 4) the Jesuit missionaries who supervised this market until arrival, re-elaboration and distribution by the West; 5) the readers inside the Church institutions; and 6) the final European intellectual consumers.

The first four actors had a prominent role in the preliminary phase of the culture exportation.

1. The Chinese readers exercised their agency influencing (indirectly or more directly) the selection of works which need to be exported. In fact, the Jesuit missionaries who followed the steps of Matteo Ricci (1552-1610) in China, embraced his 'accommodation policy' 2 and tried to spread Christianity inside the Great Wall, through an intercultural process based on the study of Chinese customs and culture. In order to accomplish this, they started reading the most relevant and widespread literature, choosing the same texts of scholars with which they had the possibility to enter in contact. $^{3}$ But also, Chinese booksellers gave them advice, indicating the books sine qua non that needed to be purchased in their collections. This is still possible to see in booklists, documents belonging to Jesuits and preserved in European Libraries, as the one provided by $\mathrm{Mr}$. $\mathrm{Hu}$, from the bookshop Shìyètáng in Xīhéyán, in Beijing, to the Jesuit Jean-François Foucquet (1665-1741), entitled Xīhéyán shìyètáng Hú shì shūpù shūdān 西 河沿世業堂胡氏書舖書單(Booklist from the Bookshop Shiyetang of Mister $\mathrm{Hu}$ in Xiheyan), today preserved in the Biblioteca Apostolica Vaticana, with the collocation Borg. cin. 357.1.4

2. The books themselves were predominant actors in this cultural exportation; the material characteristics of the book, as with its price and availability, greatly influenced its selection or not.

Furthermore, different areas and bookstores provided different kinds of literature. Jianyang was the premier publishing site from eleventh to seventeenth centuries and produced a wide range of texts, including also books for scholars (Brokaw 2007, 264); in the eighteenth century the primary source shifted to the bookstores in Sìbǎo's area 四堡, with more

2 "The accommodation of Christianity to indigenous elements of a foreign culture" (Mungello 2009, 19).

3 For a brief overview of the Chinese books collected by the Jesuits, and the possible influences on the purchase, see Dudink 1996, 156.

4 For more information, see Standaert 2015. 
poorly produced works designed for a non-elite audience; and with the late Ming $^{5}$ came a bloom of urban publishing houses, in particular in the biggest cities of Jiangnan 江南 area, as Nanjing 南京, Suzhou 苏州, Hangzhou 杭州, Yangzhou 扬州 and Jianyang 建阳 (Fan Jinmin 1998). Books printed in Jianyang and other areas in Fujian province were notorious for their inferior quality and printing mistakes, although in Nanjing and Suzhou could be also found books of better editions (Chow 2004, 81-3).

Under the Qing 清 dynasty (1644-1912), the largest publishing centre was moved north to the Imperial capital Beijing 北京 (Brokaw 2007, 265), where due to the high concentration of officials and literati, there was a high presence of bookstores with the possibility to find rare and refined editions (Chow 2004, 79). Consequently, the provenance of the book already influenced its quality and content. Choosing a book was already a choice of which culture to import, and the power of choosing was more in the hands - figuratively speaking - of books than the real acquirer. A Westerner, with limited freedom to go around China, unless in the permitted areas, ${ }^{6}$ was conditioned by the presence of neighbour bookshops or, when on occasion, by official gifts, to create his own book collection.

3. In this book trade, from China to Europe, it is necessary to consider also the restriction and regulations that were imposed by the Chinese government during the late Ming and first Qing dynasty on foreign markets and Christian missions. As can be seen in the widely translated and spread Historia de la China, written by the Augustinian friar Juan González de Mendoza, first published in 1585, where he talked of more than a hundred books purchased by the Provincial Herrada:

y trajera muchos mas (segun dijo) porque avia grandissimas librerias y valian apoco precio,siel virre y nos elo estorvara:q temiendo se por ven-

5 The particular social situation during the Ming 明 dynasty (1368-1644) is well explained in Chen Baoliang 2014.

6 Even if the Christian missionaries were tolerated at the beginning, their presence in China was dependent on the Imperial authorization; in Historia de las cosas más notables, ritos y costumbres del gran reyno de la China, translated in English as The History of the Great and Mighty Kingdom of China and the Situation Thereof (hereafter abbreviated as Historia), after a written request of Augustinians to stay in China to do their mission, it is said that: "Il Vicerè la lesse, \& rispose, che ne darebbe aviso al Rè, come haveva detto lor prima, $\&$ che dove dimàdavano, ch'i frati restassero nel Regno à predicare, diceva non poter farlo senza còsenso, \& liceza del consiglio reale" (The Viceroy read it and replied that he would inform the Emperor, as he said before, and about the request that the Friars could stay to preach inside the Kingdome, he couldn't give an answer without the Imperial consensus and authorization; the English translation is made by the author) (Historia 1586, 211). In the early eighteenth century, China had altered her previously tolerant attitude to Christian missions, and in 1724 an Imperial edict decreed the expulsion of all the foreigners from China, but not the Jesuit scientists that were working at the court. For more information see Brockey 2008. 
tura que pormedio de ellos nose supiessen los secretos del Reyno (cosa que con gran cautela procuran en cubrir a los estrangeros) les invio a dezir, nolos comprasen. Lo qual despues nocumplio: Opor la razon ya dicha, o, quiza por oluidarsela. (Mendoza 1585,115 ) ${ }^{7}$

and he would have brought a great number more, as he said, because they have found great libraries, and at a very cheap price, if the Viceroy had not forbidden it, who perhaps suspected that those books might be a means to know the secrets of their Kingdome, (which they try to keep hidden to strangers with great effort) and sent to tell him and his companions, that they must not buy any books, because they would give them the ones which they had wanted. If then, they did not observe the promise, maybe it was for the cause I said, or maybe, for oblivion. ${ }^{8}$

In the Dà Míng huìdiăn 大明会典 (The Collected Statutes of the Ming Dynasty) printed in 1509, in fact, is already mentioned the adoption of restraining measures on doing business with foreigners, as is proved by the embargo, hăijìn 海禁:

弘治十三年令、官民人等、擅造二桅以上违式大船、将带违禁货物、下海、入番国 买卖, 潜通海贼、同谋结聚、及为向导、劫掠良民者。正犯处以极刑。全家发边卫充 军。 ${ }^{9}$ (Da Ming huidian 1587, juan 132, 98)

\section{Embargo:}

In the XIII year of Hongzhi Reign (1500) it was decreed that officials and citizens, without authorization create boats bigger than a two-masted ship, carry goods violating the ban, put out to sea and enter foreign countries in order to do business; who secretly do piracy, who conspire together, as well as be their guide, who loot loyal subjects. For the principal criminals, the sentence will be a death penalty, and their family will be banished to the frontiers.

In the Dà Qing huìdian, the jurisdictional canon compiled during the beginning of the Qing dynasty, it is possible to find edicts talking about punishment in the case of wéijin 违禁, violation of the ban regarding foreign merchandise, and in the Qīndìng dà qīng huì diăn zé lì 钦定大清会典则例 (Imperially Endorsed, Collected Administrative Statutes and Precedents

7 The full original text in Spanish is available at http://reader.digitale-sammlungen.de/ de/fs1/object/display/bsb10178450_00005.html (2018-04-28).

8 All translations in this paper are made by the author, unless otherwise indicated.

9 《大明会典》卷一百三十二. The text is available at https://ctext.org/wiki.pl?if=gb\&res=70663 O\&remap=gb (2018-06-09). 
of the Great Qing) written in the Qianlong period (1736-1796), were listed many goods that were prohibited to be sold to foreigners, in which also books of history were included..$^{10}$

In fact, the exportation of goods had always been regulated by the central authority which became stricter with the passage to the Qing Dynasty.

4. Despite the difficulties, the Jesuit missionaries were one of the most actively acquirers of Chinese books, in part for their personal necessity to get to know Chinese in order to improve the result of their religious mission, in part for the path taken as cultural mediators between Europe and China. Until the suppression of the Order in 1773, collections of Chinese books were carried on inside Jesuit Libraries not only in Europe, but also in China (Golvers 2010). Jesuits interest and agency on importing Chinese culture is particularly evident in their way of dealing with the translation of texts; the religious education received in College, and the humanistic philological studies led their interpretation of Chinese culture. In some cases, the reading of texts was carried out with a specific purpose, as is possible to see in some French Jesuits who adopted 'Figurism', a particular system of interpretation of Chinese texts, aiming to find in them traces of Christianity. For example, the 'Ykingnistes', as they were called by the Jesuit missionary Joseph-Marie Amiot (1718-1793), were a group of Jesuit missionaries, who regarded the Yijing 易经 (The Book of Changes) as a prophetic book which contained the mysteries of Christianity (Mungello 1989, 309-10).

The final receptors of this Imported Culture were 5) the readers inside the Church institutions, and 6) the European citizens of the Respublica literaria.

The Roman Church was interested in the Chinese books as proof and first source of their work in China, but also because books permitted an investigation into the territory in which the mission was carrying on, and consequently, to control, evaluate and act in order to change the strategies applied to the territory.

European intellectuals, on their own, were fascinated by Chinese culture and tried to find inspiration for their idea (e.g., Voltaire, Rousseau, Leibniz, and Condorcet are just a few of the philosophes who paid attention to the study of China history and thought).

It is possible to identify three steps (translation-reception-influence) in order to analyze how the agency of Chinese books conflicts and coincides with the agency of other actors in this trans-cultural circuit. 


\section{Agency in Translating: 'do ut des'}

Praeco sum, seu relator, \& non author doctrinae, quam palàm facio. Credo, \& amo antiquitatem, ex quâ studiosè suffuso, \& excerpo quae ad rem meam; imitatus in me ipso famosus illum senem Pûm

This is how Jesuits in 1687 translated the passage in the Lunyu ${ }^{\mathbf{1 1}}$ 述而不 作，信而好古，竊比於我老彭。in which Confucius affirms that “I transmit, I do not create"12 to indicate his role as spokesman of the past. But is it really possible to be a complete passive reader without interfering with the text? As Umberto Eco stated otherwise, the text is a 'lazy machine' that makes other people do part of its job (Eco 1979), giving an active role to the reader in the process of dealing with and interpreting texts. If also the statement of Confucius could create enough reasonable doubt about how it is possible, philologically speaking, to truly transmit and not change the texts of Chinese cultural heritage, then, in the case in which they imported books, transporting them from one cultural and linguistic context to another, changing the receptor reader and knowledge background, the doubt would become even more obvious: is it still possible to be a faithful transmitter and not a creator? If the reader changes, can the meaning and consequently the agency of the text still be the same? According to Derrida

à la notion de traduction, il faudra substituer une notion de transformation : transformation réglée d'une langue par une autre, d'un texte par un autre. $(1972,31)$

In fact, it is more realistic to talk about transformation than translation, because in the case of importing books, the dealer is not sharing the same cultural heritage, and his interpretation is influenced by different factors and actors that cooperate in changing the perception of the books, a condition that is more evident in the case when dealing with the translation process where there is a religious order such as that of the Jesuits.

As we said earlier, behind their translation works there were, firstly, a strong ideological connotation, which influenced the choice of words and final result of the translation, and, secondly, they were driven by interest inside the Jesuit Order itself. That is why to the 'transformed' translation we can also suggest the implication of the adjective 'interested'.

11 See Meynard $(2015,245)$ for the complete Chinese text and its translation in Latin.

12 The complete translation of the passage Lunyu 7.1 can be consulted in the Italian version, provided by Attilio Andreini $(2017,7)$ (Trametto non creo: credo negli antichi, li venero e, nel far ciò, oso paragonarmi al Venerabile Peng) and the English translation of Burton Watson $(2007,48)$ (The Master said, A transmitter and not a maker, trusting in and loving antiquity, I venture to compare myself with our Old Peng). 
The first attempts at translating Chinese books are those related to the study of the canonical books of Confucianism - Daxue 大学 (The Great Learning); Zhongyong 中庸 (The Doctrine of the Mean); Lunyu 论语 (The Analects); Mengzi 孟子 (Mencius) - that materialized at the end of the sixteenth century with the Jesuit Michele Ruggieri (1543-1607), then Matteo Ricci with his lost translation - in 1595 he sent a copy of his translation of the Four Books to the Superior General of the Society of Jesus, Claudio Acquaviva, but, unfortunately, the manuscript has been lost (Standaert 2001, 863) -, and then arrived at the first team-work translation, such as that coordinated by the Portuguese Jesuit Inacio Da Costa in 1660-1662 with his group of four Jesuits (Prospero Intorcetta, Christian Herdtrich, François de Rougemont and Philippe Couplet): Sapientia Sinica, containing the Chinese-Latin bilingual translation of the Daxue, the first half of Lunyu and a four-page biography of Confucius. The project was followed by the translation of the Zhongyong supervised by Intorcetta and published as Sinarum Scientia politico moralis, also containing a more expanded Vita Confucii. Then, in 1687, Couplet, with the support of the King of France Louis XIV, published Confucius Sinarum Philosophus, sive scientia Sinensis (Confucius, The Philosopher of China, or the Chinese learning; abbreviated hereafter as Sinarum Philosophus), the first complete translation of Daxue, Zhongyong, Lunyu, and Vita Confucii (Meynard 2015, 18).

Focusing on the edition of the Sinarum Philosophus, we can analyze how the text becomes a clear means of agency. In fact, the publication of this translation was generated by a particular political need of the Order: to achieve consensus on the evangelical strategy they had adopted in China; that is - in the process of evangelical immigration in a different culture - to reach forms of integration and compromise with other types of local worship. This attitude was subjected to great criticism and unleashed, inside the Roman Church, the Question of Rites: is it possible to tolerate cults if they prove to be antithetical to the Christian creed, such as rituals towards the personality of Confucius, and not be obliged to oppose them? The translation of the Confucian texts was to serve precisely to demonstrate how the thought of Confucius was not dissimilar to Christian ideology, and to justify the Jesuit tolerant politics. It is not by chance that in the Sinarum Philosophus, Confucius is clearly portrayed as a Christian ante litteram. ${ }^{\mathbf{1 3}}$

13 The expression can be deducted by the following passage dedicated to the biography of Confucius: "virtutem sane fuisse Philosopho, non meram speciem fucumque virtutis. Quid? Quod nostris temporibus haud defuerint è Litteratorum ordine, qui vel amplexi jam Religionem Christianam, vel hujus integritate sanctitateque probe saltem perspecta, non dubitanter affirmarunt, sperari posse Philosophum sum, si quidem vixisset aetate nostra, primum fuisse futurum, qui ad Christi legem transivisset." (the Philosopher had true virtue, and not a mere appearance, or mask, of virtue. Why? Because, in our present time, there is no lack of people among the literati who, either having already converted to Christianity, or at least having honestly understood its soundness and holiness, do not hesitate to affirm 
Furthermore, the politic agenda inside the translation of Confucian texts was clearly made explicit affirming:

A careful reader will understand from all these things that the authority of this man will be greatly useful to missionaries, since the Chinese are still devoted to their Master and his books. It would be possible to use his authority to confirm the Christian truth, in the same way as in the past we saw the Apostle of the Nations [St Paul], using the authority of the Greek poets among the Athenians. (Meynard 2015, 613)

This statement summarized the 'propaganda' agency of the Order also in the reverse direction, from West to China, which consists in making the Christian message more appealing, translating - or better, transforming - it in combination with existing texts, terminologies and images from well-established and authoritative tradition to explain and spread their Christian belief.

A striking example is the case of Guanyin or Avalokitesvara, a Bodhisattva, belonging to the tradition of Mahayana Buddhism (Cheng 2000, 421). Guanyin translated in Chinese as 'the Lord who hear the sounds', the listener of prayers, is an intercessor full of compassion for all troubled beings whose image, entering in China, undergoes a process of feminization as early as the eighth century. The common iconography of Guanyin when Jesuits arrived in China was as a woman with a white dress, able to grant the grace of childbirth and so frequently portrayed with a baby next to her; because of this iconographic resemblance, often the cult for Guanyin was used by Jesuits as a metaphor of the Holy Mary, Mother of Christ.

However, there is a case in which the Jesuits themselves, in some way, became the object of ventriloquism.

Going back to the Chinese texts that were exported from China and arrived in Europe, in the University Library of Genoa, ${ }^{14}$ which preserves the original Jesuit College Library, there is a section of books written in Chinese. In this collection there is a volume, catalogued in Latin as Prayer to the Virgin Mary; ${ }^{15}$ but if you read the Chinese book, you find that it is a perfectly preserved printed version of Gaowang Guanshiyin jing (Sutra of the Great King Avalokitesvara), with no connection whatsoever to Christian belief. So, who is the dummy?

If, in part, the books were the victim of translation, understood as a combination of the Latin action of tradeo, being transported from the context of

that, if their Philosopher had lived until today, he would certainly be first to want to cross over to the Christian faith) (Meynard 2015, 607).

14 For more information on the College of the Jesuits in Genoa, see Cosentino 1982.

15 The annotation on the title was later removed on the book with a different calligraphy. 
origin to a different one, and transverto, transforming the meaning of the text to meet receptors' needs, it is also true that the books themselves were the protagonists of a diffusion never conceived as possible in a continent totally alien to them, in a sort of almost fair exchange do ut des, giving to receive between puppet and puppeteer.

\section{Agency on Value, Mutability of Things in Recontextualization}

With the transfer of the text from the context of export to the different one of import, its value and the following perception mutates.

The objects, in themselves, are constituted by some specific physical-material characteristics, which involve properties, functions, uses of objects, and end up constituting their identity; but at the same time, objects are also changing entities susceptible to redefinitions which means a "mutability of things in recontextualization". ${ }^{16}$ So, in the case of Chinese books, how were they received in Europe?

As it had happened for other Chinese objects, once translated into the European collectors' hands, the majority of the books were 'westernized', changing their traditional Chinese bookbinding into a Western book format, with the addition of a hardcover and end sheet (realized sometime with marbled paper, not used in Europe until the middle of the seventeenth century, or watermarked paper); ${ }^{17}$ a lot of Chinese books still preserved in European Libraries faced the problem of undergoing a western bookbinding that resulted in the loss of their original cover and first pages, with in some cases the consequent deletion of important information as to dating, publisher and title. In some cases, the books are made incomplete, because a single or few juăn 卷 'scroll' or 'fascicle' - term used as a counting unit for Chinese books, corresponding in general to one chapter - were bounded as a distinct book, so only parts of the text have been transmitted to today.

Even if books were mutilated and changed, they still could acquire new meaning and in some way act on their readers.

And it is precisely this peculiar mutability of things in their social recontextualization that made researchers go beyond the idea of a mere static object, the puppet we mentioned at the beginning, and consider it as a living actor, whose biography it is necessary to study, because it was able to re-adapt to new contexts.

16 The concept "mutability of things in recontextualization", also used in the title of the paragraph, comes from Thomas $(1991,28)$.

17 To get an idea of the peculiarity modification of Chinese books in Western collections, see IFLA website (International Federation of Library Associations and Institutions): From China to Cambridge: modification of rare Chinese printed books within Cambridge College libraries. URL http://library.ifla.org/1692/1/088-richard-en.pdf (2018-04-28). 
In this sense, a clear example is the case of Chinese encyclopaedias collected in Europe: the rìyòng lèishū 日用类书 (Encyclopaedias of Daily Use). These books were not used by scholars as an aid to study for the exams, but as a summary of practical knowledge for readers with a basic literacy. The encyclopaedias were full of pictures, and were produced with a large print run, characterized by the presence of numerous simplified characters and misprints. ${ }^{18}$ Even the riyong leishu encyclopaedias that are still visible today in some European libraries show the same low quality press as the versions widely circulating in China at that time; but in that case the book's agency is changed drastically; from 'popular'19 text, produced in large quantities in China appealing to non-elite readers, to elitist object once transferred in Europe. From the Westerners' point of view, the Riyong leishu became a source to know Chinese culture, even if it was not born as the product of the literate class, and it was more representative of laobaixing 老百姓, the average people, rather than intellectuals. In China Illustrata ${ }^{20}$ published in Amsterdam in 1667 by Athanasius Kircher (1602-1680), some pictures were copied from the encyclopaedias as the chapter on the history of characters. In the Ambrosian Library of Milan (one of the earliest public libraries in Europe, founded by Cardinal Federico Borromeo in 1609), is preserved as a treasure the fragment of just one page (in reality, two pages wrongly bounded together as one), ${ }^{\mathbf{2 1}}$ proving how the agency of imported books changes, redefining the value and the role of the text itself.

But what precisely was the Chinese imported culture that spread to Europe?

The summary list, based on surveys of preserved Chinese book collections in the Jesuit libraries that are still possible to consult today, basically contains Confucian texts, Buddhist texts, Ben cao gang $m u$ 本草纲目 (Compendium of Materia medica), various encyclopaedic works as Riyong leishu, Sancai tuhui 三才图会 (Illustrated compendium of the Three Powers), astronomy books on observation of planets, constellations, on the eclipse phenomenon or calendar. Regarding the translated books, principally they are focused on Confucian texts, Mai Jing 脉经 (The Pulse Classic), discussion on Yijing 易经 (The Book of Changes), studies on the flora, ars medica Sinensis, and astronomy. In this list we did not consider the

18 For a complete description of the type of Encyclopedias in China, see Bauer 1966 and Sakai 2011.

19 For the definition of 'popular', see the debate in Brokaw (2007, 266-74), in which is analysed the question of the readers of riyong leishu encyclopedias.

20 The complete title is China monumentis qua sacris qua profanis, nec non variis naturae et artis spectaculis, aliarumque rerum memorabilium argumentis illustrate.

21 Milano, Ambrosiana, 12.S.Q.V.VIII.15/5. 
books written in Chinese by the Jesuits, because these books are not representative of the Chinese culture, but a product of the missioners' work. However, due note should be taken on this production and its presence in all the Jesuit libraries, which contained a Chinese books section; these books were widely circulated as well as greatly influenced the cultural and scientific debate in late Ming and early Qing China. ${ }^{22}$

\section{Agency in Constructing the Chinese Image: the Influence of Books}

The last stage of this analysis of the means of action of imported culture, is its influence.

Those books that are still visible today in the collections of many European libraries have not only been the subject of translation but with their very presence - or absence - have acted on the formation of the Chinese image in Europe.

First, books had a deep impact in portraying China to the West; the Chinese texts produced attraction, fascination, and contributed to create in European intellectuals' minds a certain idea of China, mysterious, ancient and wise.

Et puisque j'ai commencé de vous dire ingénument ce que je pense des livre canoniques \& des characters Chinois, j'ajouterai ce que je crois qu'on doit suposer comme une chose très certaine, savoir que les uns $\&$ les autres sont beaucoup plus anciens que les Chinois mêmes, \& que ce sont des monumens fideles de la tradition lae plus ancienne que les Peres communs de toutes les nations ons laissèes à leurs descendans, $\&$ que les Chinois ont conservé plus soigneusement que les autres. (Kortholt 1734,79) ${ }^{23}$

22 This is another type of 'agency', connected to the work of Jesuits in China and the circulation of Chinese books, but acting in the reverse direction of the one chosen as a case study for this article, so it will be not further analysed although the extreme importance of the phenomenon; there were many translations carried out under the control of the Jesuits from Western languages to Chinese, as the partial translation of the tractatus of Andrea Pozzo, Perspectiva pictorum et architectorum, translated by Nian Xiyao 年希堯 under the guidance of Giuseppe Castiglione SJ (Corsi 2010, 93-100), or the production of books in geographical, astronomical field under the request of Chinese emperors (Golvers 2012).

23 The epistolary correspondence of Leibniz and Bouvet is collected in Recueil de diverses pièces sur la philosophie, les mathématiques, l'histoire, etc., avec II lettres où il est traité de la philosophie et de la mission chinoise envoyées à Mr. de Leibnitz par le P. Bouvet, Jesuite à Pekin (1734), Paris, BNF, Z-23579. The digitalized version is available at http://gallica. bnf.fr/ark:/12148/bpt6k110509c (2018-04-28) 
And since I have begun to frankly tell you what I think of the Chinese canonical books and Chinese characters, I would add what I believe should be granted as something very certain, that both the one and the other are much older than the Chinese themselves, and that they are the faithful monuments of the most ancient tradition, which the Fathers common to all the nations have left to their descendants, and which the Chinese have preserved more accurately than the others.

This is how the French Jesuit Joachim Bouvet (1656-1730) in a letter written in Beijing the Eighth of November, 1702, responded to the question about China that the German philosopher and mathematician Gottfried Wilhelm Leibniz (1646-1716) previously asked him.

Leibniz, interested in Chinese philosophy, in 1697 published Novissima sinica, historiam nostri temporis illustratura, on the basis of the information he acquired through his epistolary correspondence with Jesuits and the translations they procured to him. In this book's preface, he argued:

Quod si ita pergitur, vereor ne mox omni laude Sinensibus inferiores simus: quæ non ideo dico quod illis lucem novam invideam, cum gratuler potius; sed quod optandum sit vicissim nos discere, quae magis adhuc in rem nostram essent, usum maxime Philofophiæ practicæ, $\&$ emendatiorem vivendi rationem, ut de aliis eorum artibus nunc nil dicam. Certe talis nostrarum rerum mihi videtur esse conditio, gliscentibus in immensum corruptelis, ut propemodum necessarium videatur Missionarios Sinensium ad no mitti, qui Theologiæ naturalis usum praxinque nos doceant, quemadmodum nos illis mittimus qui Theologiam eos doceant revelatam. Itaque credo, si quis sapiens, non formæ Dearum, sed excellentiæ populorum judex lectus esset, pomum aureum Sinensibus daturum esse (Leibniz 1699, 16-17)

But going on like this, I am afraid that soon we will be inferior to the Chinese in every field: certainly I do not say this because I envy them this new light - rather I rejoice for it - but because it will be better that We learn from Them those things that so far could be more advantageous for us, especially the use of Practical Philosophy and a more honest kind of life, not to mention now their other arts. To my opinion, is it clear that our condition, with corruption that is spreading immeasurably, is such as it's almost necessary sending Chinese missionaries to us, to teach us the use and practice of Natural Theology, as we send them our Missionaries to teach the Theology of Revelation. Therefore, I believe that, if some wise man had been chosen capable of judging not the beauty of the Goddesses but the excellence of the peoples, they would give the Golden Apple to the Chinese. 
Leibniz can be interpreted as the biggest success of Jesuits agency on European intellectuals, because through the imported Chinese culture he saw in this philosophy a sort of Platonic-Christian conception of the universe.

The information on Chinese culture was a common reference among the philosophes of the Enlightenment, whose aim was to reform Europe; is it possible to say that China, indirectly, had contributed to the reconstruction of the Western world.

In fact, the influence of Chinese literature on Enlightenment philosophers had also an unexpected outcome. The image of China that transpired from the imported culture was a land of harmony and the model of the perfect state, admired as an inspirational country while Europe was criticized instead (Shi 2007, 93-111).

Another influence of the imported Chinese culture was the awareness of the existence of an ancient developed country, in which studies on philosophy, medicine and astrology were carried on for a long time, and the books that arrived in Europe were concrete proof of it. Such information was transformed into the instrument, for some intellectuals, to confute the Jesuit thesis of a worldwide shared religious belief, negating the consensus gentium on the existence of God. China became the myth of a society free from religious imposition, without the rooting of Church inside the power institutions, and was used as the stimulus to pursue atheistic beliefs, with a completely different result in comparison to how Jesuits intended to manipulate Chinese culture.

To sum up, analyzing the actors' agency on the imported Chinese culture, we can say that the intention of Jesuits to use books and culture as a tool to obtain Christian conversion in China, and contemporary with this, to get consensus for their missions from European readers, did not obtain the targeted result.

From one side, after the questions of rites arrived to China, provoking the response of the Kangxi Emperor 康熙 (1654-1722) and his interdiction of missions in China without Imperial authorization, ${ }^{24}$ the dream to see a Christian China became more unrealistic than ever. From the other side, the papal bull Ex illa die, ${ }^{25}$ issued by Clement XI in 1715 against the accommodation policy inspired by Ricci, decreed the failure of their strategies and later, the complete end of the Order in 1773.

The Catholic Church, for its part, between the late Seventeenth and twentieth century, had tried to bypass the Jesuits intermediation and the

24 The ban on Christianity within China was transformed into an effective law by his successor, the Emperor Yongzheng 雍正 (1678-1735), in 1724.

25 Full title: Confirmatio, et innovatio constitutionis incipientis: Ex illa die: a Clemente Papa $X I$. It is possible to consult the complete text at https://archive.org/details/bub_gb_FRwbc9xWYHQC. 
patronage systems of the Crowns of Portugal and Spain over the Far East missions. The papal Sacred Congregation for the Propagation of the Faith (Propaganda Fide), based in Rome, sent its missionaries through pathways offered by different rival powers, such as France or Britain (Menegon $2017,27)$. As a result, the intention of the Church to restore its direct power of action in China failed with the total closure of China to Western religion.

It seems that just two actors emerged as the winner of these conflicts: the Chinese imported books and its new readers. Although mutilated, changed and translated, books still had the power to become part of a history to which they didn't originally belong, entering the libraries of European intellectuals who collected and looked at them.

If we consider also the censorship that operated in the choice of which books needed to be exported, and which not, then a question arises: who influenced the choice of books, which to send overseas and which not to? The texts in Europe today are the result of the independent choice of the Jesuits, addressed exclusively to the objective of their mission, even at the cost of subterfuge - and therefore an even more calculated and important choice - or are they the result of another agent? On the basis of the texts, the Chinese image was formed in the common European imagination, so understanding what and who influenced the choice of the Imported culture is a question of great interest.

\section{Conclusion}

Pondering the 'agency' of a text implies different problems, especially if it is an imported text that needs to be interpreted; where does the agency reside, in the reader, in his society, or in the object itself? The relationship between the actors is so deeply bound, that a separation does not seem possible, in an infinite game of ventriloquism between them.

If, moreover, the early reader is a Jesuit missioner, the problem becomes even more complex: for a strictly structured religious order as the Society of Jesus, that controlled every movement of its members, everything must proceed in response to the norms of the institution and acting in accord with it. A control that starts from the formation of its members, based on the Ratio Studiorum (1599), ${ }^{26}$ the text dedicated to the structure and content of the Jesuit educational programme, and takes concrete form with the efficient long-distance network connecting all the Assistances and Provinces

26 On this topic see Donohue 1936. 
of the Society with the Generalate Archive, located at Rome ${ }^{27}$ that collected all the information from abroad as in the Litterae annuae. Therefore, also the reading of Chinese texts was moved by a particular 'control'. Not without reason, the translated and disseminated Chinese texts was mostly the result of a team work, and not of a single independent author, supervised and confirmed by the Father General. Behind the reading of the texts was hidden a strong 'agency', intended as an intention to act on the texts in order to obtain a precise result: support for their mission in China.

However, the corresponding results did not fit in with the anticipated action-effect chain: the information on Chinese culture, language and philosophy, its influence in the secular audience, caused some ostracism in the religious environment.

It seems that the willingness of the creator of the transformed text is not enough to control the effective impact, as if the books by themselves, despite having been translated, interpreted and modified, have an autonomous life regardless of the intention of its producer, by acting on their own.

We have described the different actors and how they interacted in this process of importing Chinese texts in Europe; many interests move the pawns on this chessboard and the consequences that this game causes are also various.

It would be interesting to carry forward further investigation on who was the principal leader in the choice of books and the motivation behind which one to import or not. In this regard, it will be necessary not only to do a reconstruction of the Chinese book collections in the libraries between the seventeenth and eighteenth centuries, but also to do a reconstruction in 'negative', that highlights which books were not selected and why.

Nowadays, China is trying to construct outside its border a national reputation, through different projects (e.g. establishing more Confucius Institutes ${ }^{28}$ abroad and promoting cultural/economic international programmes, as One Belt One Road, ${ }^{29}$ just to name a few). The aim behind these investments is to build outside of China, an own image of China itself, without any foreign (mis)interpretation or interference. Is it possible that

27 ARSI, (Archivum Romanum Societatis Iesu), the Archives of the General Government of the Society of Jesus.

28 The Confucius Institute, Kongzi xueyuan 孔子学院, is a non-profit public educational organization affiliated with a department of the Ministry of Education of the People's Republic of China, Hanban 汉办, whose aim is to promote the learning of Chinese language and culture, establishing the Institute's schools and facilitating cultural exchanges. See Paradise 2009, 647-69.

29 Yìdài yīlù 一带一路; The 'One Belt, One Road' concept was first presented during Xi Jinping's visit to Kazakhstan and Indonesia in 2013; the aim of this project is "to connect China, Asia and Europe in terms of trade and economic interaction via a land route ('the belt') as well as a maritime route ('the road')" (Brødsgaard, Koen 2017). 
at the end of Ming and beginning of Qing dynasty, there was already a willingness to build a Chinese cultural image outside the borders, using books as tools to control what foreigners could know about China and what not?

Studying the history of Chinese books and documents preserved in Europe can help us reconstruct the complicated policy and strategies which moved this trans-cultural process of imported culture, looking from both sides.

\section{Bibliography}

Ahearn, Laura M. (1999). “Agency”. Journal of Linguistic Anthropology. 9(1-2), 12-15.

Andreini, Attilio (a cura di) (2012). Trasmetto, non creo. Percorsi tra filologia e filosofia nella letteratura cinese classica. Venezia: Cafoscarina.

Appadurai, Arjun (ed.) (1986). The Social Life of Things: Commodities in Cultural Perspective [online]. Cambridge: Cambridge University Press. DOI 10.1017/CB09780511819582 (2018-04-26).

Bauer, Wolfgang (1966). "The Encyclopaedia in China”. Cahiers d'histoire mondiale. Journal of World. History, 9(3), 665-91.

Bretelle-Establet, Florence; Chemla, Karine (éds.) (2007). “Qu'était-ce qu'écrire une encyclopédie en Chine? / What Did it Mean to Write an Encyclopedia in China?" [online]. Extrême Orient, Extrême Occident, special issue, 29.

Brockey, Liam Matthew (2008). Journey to the East: The Jesuit Mission to China, 1579-1724. Cambridge: Harvard University Press.

Brokaw, Cynthia (2007). "Book History in Premodern China: The State of the Discipline I". Book History, 10, 253-90.

Brokaw, Cynthia J.; Kornicki, Peter F. (eds.) (2016). The History of the Book in East Asia. London: Routledge.

Brødsgaard, Kjeld Erik; Koen, Rutten (2017). “The Era of Xi Jinping (20122016)" [online]. From Accelerated Accumulation to Socialist Market Economy in China: Economic Discourse and Development from 1953 to the Present. Leiden; Boston: Brill, 154-64. URL http://www.jstor.org/ stable/10.1163/j.ctt1w8h2tj.11 (2018-05-01).

Burton, Watson (trans.) (2007). The Analects of Confucius. New York: Columbia University Press.

Chen Baoliang 陈宝良 (2014). Ming dai shehui zhuanxing yu wenhua bianqian 明代社会转型与文化变迁(Social Transformation and Cultural Change in Ming Dynasty). Chongqing: Chongqing daxue chubanshe.

Cheng, Anne (2000). “Dall'introduzione del buddhismo alla formazione del pensiero moderno". Storia del pensiero cinese, vol. 2. Torino: Einaudi. 
Chinese text project. s.v. “钦定大清会典则例 (Qinding Da Qing huidian zeli)” [online]. URL https://ctext.org/wiki.pl?if=en\&chapter=165888\&rem $a p=g b(2018-11-20)$.

Chow, Kai-Wing (2004). Publishing, Culture, and Power in Early Modern China. Stanford: Stanford University Press.

Cooren, François (2010). Action and Agency in Dialogue: Passion, Incarnation, and Ventriloquism. Philadelphia (PA): John Benjamins.

Corsi, Elisabetta (2010). "La fortuna del Trattato oltre i confini dell'Europa”. Bösel, Richard; Salviucci Insolera, Lydia (a cura di), Mirabili disinganni. Andrea Pozzo (Trento 1642-Vienna 1709) pittore e architetto gesuita. Roma: Artemide, 92-100.

Corsi, Elisabetta (2012). "Editoria, lingue orientali e politica papale a Roma tra Cinquecento e Seicento". Barreto, Lúis Filipe; Wu, Zhiliang (eds.), Port Cities and Intercultural Relations, 15th-18th Centuries. Lisbon: CCCM, 179-206.

Cosentino, Giuseppe (1982). “Il Collegio gesuitico e le origini dell’Università di Genova”. Miscellanea storica ligure, 15, 57-137.

Derrida, Jacques (1972). Positions. Paris: Les Édition de Minuit.

Donohue, John W. SJ (1936). Jesuit Education: An Essay on the Foundation of Its Idea. New York: Fordham University Press.

Dudink, Adrian (1996). "The Inventory of the Jesuit House at Nanjing Made up during the Persecution of 1616-1617". Western Humanistic Culture Present to China by Jesuit Missionaries (XVII-XVIII Centuries). S.1.: Institutum Historicum Societatis Iesu, 119-57.

Eco, Umberto (1979). Lector in fabula. Milano: Bompiani.

Elman, Benjamin A. (2007). "Collecting and Classifying: Ming Dynasty Compendia and Encyclopedias (Leishu)" [online]. Bretelle-Establet, Chemla 2007, 131-57. URL https://wWw.jstor.org/stable/42635797 (2018-04-28).

Emirbayer, Mustafa; Mische, Ann (1998). “What Is Agency?”. The American Journal of Sociology, 103(4), 962-1023. DOI 10.1086/231294 (2018-04-26).

Fan Jinmin 范金民 (1998). Ming Qing Jiangnan shangye de fazhan 明清江南 商业的发展 (Commercial Development of Ming-Qing Jiangnan). Nanjing: Nanjing daxue chubanshe.

Golvers, Noël (2010). “Bibliotheca in cubiculo: The 'Personal' Library of Western Books of Jean-François Foucquet, SJ in Peking (Beitang, 1720) and the Intertextual Situation of a Jesuit Scholar in China". Monumenta Serica, 58, 249-80.

Golvers, Noël (2012). Libraries of Western Learning for China: Circulation of Western Books Between Europe and China in the Jesuit Mission (ca. 1650-ca. 1750). Leuven: Ferdinand Verbiest Institute.

Knappett, Carl; Malafouris, Lambros (eds.) (2008). Material Agency: Towards a Non-anthropocentric Approach. New York: Springer Science \& Business Media. 
Kortholt, Christian (1734). Recueil de diverses pièces sur la philosophie, les mathématiques, l'histoire, etc., avec II lettres où il est traité de la philosophie et de la mission chinoise envoyées à Mr. de Leibnitz par le P. Bouvet, Jesuite à Pekin. Hambourg: A. Vandenhoeck Hambourg.

Leibniz, Gottfried Wilhelm (1699). Novissima Sinica Historiam Nostri Temporis Illustratura: In quibus De Christianismo publica nunc primum autoritate propagato missa in Europam relatio exhibetur, deque favore scientiarum Europæarium ac moribus gentis \& ipsius prœsertim Monarchœ, tum \& de bello Sinensium cum Moscis ac pace constituta,multa hactenus explicantur. S.n.: s.l.

Li Dongyan 李东阳 (ed.) (1587). Da Ming huidian 大明会典 (The Collected Statutes of the Ming Dynasty) [online]. Beijing: Nei fu kan ben, Wanli. URL https://ctext.org/wiki.pl?if=gb\&res=706630\&remap=gb (201806-09).

Li Weihong 刘卫红 (2017). “Zhengzhi yinyu yu guojia xingxiang de huayu jiangou” 政治隐喻与国家形象的话语建构《平易近人-习近平的语言力量》评介 (The Discursive Construction of Political Metaphors and National Image. Comments on 'Wit and Vision': The Power of Xi Jinping's Language). Journal of Zhongyuan University of Technology, 28(2), 29-41.

de Mendoza, Juan González (1586). Dell'historia della China descritta dal p.m. Gio. Gonzalez di Mendozza dell'ord. di s. Agost. nella lingua spagnuola. Et tradotta nell'italiana dal magn. m. Francesco Auanzo, cittadino originario di Venetia. Parti due, diuise in tre libri, \& in tre viaggi fatti da i padri Agostiniani, \& Franciscani in quei paesi.... Con vna copiosissima tauola delle cose notabili, che ci sono. Transl. in Italian by Francesco Avanzi. Roma: appresso Gio. Angelo Ruffinello.

Menegon, Eugenio (2017). “Interlopers at the Fringes of Empire: The Procurators of the Propaganda Fide Papal Congregation in Canton and Macao, 1700-1823" [online]. Cross-Currents: East Asian History and Culture Review, E-Journal, 25, 26-62. URL https://cross-currents. berkeley.edu/e-journal/issue-25/menegon (2018-04-08).

Meynard, Thierry SJ (2015). The Jesuit Reading of Confucius: The First Complete Translation of the Lunyu (1687) Published in the West. Leiden: Brill.

Montanari, Giacomo; Wojtyła, Arkadiusz; Wyrzykowska, Małgorzata (eds) (2015). Jesuits and Universities. Artistic and Ideological Aspects of Baroque Colleges of the Society of Jesus. Examples from Genoa and Wrocław. Wrocław: Wrocław University Press.

Mungello, David Emil (1989). Curious Land. Jesuit Accomodation and the Origins of Sinology. Honolulu: University of Hawaii Press.

Mungello, David Emil (2009). The Great Encounter of China and the West, 1500-1800 (Critical Issues in World and International History). 3rd ed. Lanham (MD): Rowman \& Littlefield Publishers.

Standaert, Nicolas (2001). Handbook of Christianity in China (635-1800). Leiden: Brill. 
O'Malley, John (1999).The Jesuits: Cultures, Sciences, and the Arts, 15401773. Toronto: University of Toronto Press.

Paradise, James F. (2009). "China and International Harmony: The Role of Confucius Institutes in Bolstering Beijing's Soft Power". Asian Survey, 49(4), 647-69.

Reed, Marcia; Demattè, Paola (eds.) (2007). China on Paper: European and Chinese Works from the Late Sixteenth to the Early Nineteenth Century. Los Angeles: Getty Research Institute.

Sakai, Tadao 酒井忠夫 (2011). Chūgoku nichiyō ruishoshi no kenkyū 中国日 用類書史の研究 (Research on the History of Chinese Encyclopaedias for Daily Use). Tōkyō: Kokusho Kankōkai.

Shi, Zhan (2007). "L'image de la Chine dans la Pensée Européenne du XVIIIe Siècle: de l'Apologie à la Philosophie Pratique". Annales Historiques de la Révolution Française, 347, 93-111.

Standaert, Nicolas (2001). Handbook of Christianity in China (635-1800). Leiden: Brill.

Standaert, Nicolas (2015). “Jean-François Foucquet's Contribution to the Establishment of Chinese Book Collections in European Libraries: Circulation of Chinese Books". Monumenta serica, 63(2), 361-424.

Thomas, Nicholas (1991). Entangled Objects: Exchange, Material Culture, and Colonialism in the Pacific. Cambridge (MA): Harvard University Press.

Zurndorfer, Harriet T. (2013). "The Passion to Collect, Select, and Protect". König, Jason; Woolf, Greg (eds.), Encyclopaedism from Antiquity to the Renaissance. Cambridge: Cambridge University Press, 505-28 DOI 10.1017/CB09781139814683.029. 